\title{
COVID-19 and Telework: An International Comparison
}

\author{
HIROSHI ONO
}

Hitotsubashi University Business School, Japan

\section{TAKESHI MORI}

Nomura Research Institute, Japan

\begin{abstract}
This paper uses identical surveys conducted in July 2020 in eight countries - U.S., U.K., Germany, Italy, Sweden, China, South Korea, and Japan - and examines teleworking within and across these eight countries. We seek to answer the following questions: (1) Which demographic and socioeconomic groups are more likely to telework? (2) Is there any association between telework and other work-related experiences such as life satisfaction and perceived productivity at work? Across countries, we observe that teleworking was higher in countries that imposed strict lockdowns, such as China, and lower in countries that had soft lockdowns, such as Japan. Within each country, there are notable differences in teleworking between low- and high-income persons, and between those employed in small versus large firms. We also find that people who used telework before COVID-19 report higher life satisfaction compared to those who started using telework for the first time after the COVID-19 outbreak.
\end{abstract}

Keywords: COVID-19, telework, digital inequality

Hiroshi Ono: stdhono@gmail.com Date submitted: 2020-12-31

Copyright (C) 2021 (Hiroshi Ono, Takeshi Mori). Licensed under the Creative Commons AttributionNonCommercial-NoDerivatives 4.0 International Public License. Available at: http://journalqd.org 


\section{Introduction}

COVID-19 has been a great disruptor in our lives, at home and at work. Around the world, governments responded by imposing lockdowns and stay-at-home orders in order to minimize human contact. Although these measures helped to contain the spread of the virus, they also introduced significant challenges to our economy and society. People could no longer work at the office, but they had to keep working in order to earn a living, and companies had to keep operating in order to stay in business.

Against this backdrop, telework became the natural response to the crisis. Telework allows companies to keep operating, and people to keep working without having to come to the office. Aside from lowering the risk of infection, telework has benefits associated with time and space, for example, avoiding long commutes and business travel and allowing workers to spend more time at home (Bailey and Kurland 2002; Nilles 1975).

However, as previous literature on digital inequality has informed us, the introduction of new technologies often results in an uneven distribution which is usually skewed towards a privileged group (DiMaggio et al 2001; Robinson et al 2015). The pattern of who has access to the new technology and who does not is far from random, but oftentimes follows a systematic progression, especially in early stages.

In this paper, we examine patterns of telework adoption within and across countries. Our empirical analysis is made possible through comparable individual-level microdata on teleworking collected at the height of the pandemic in July 2020 in the following eight countries: U.S., U.K., Germany, Italy, Sweden, China, South Korea and Japan. The survey asked respondents for the timing of telework adoption, specifically, if they started before COVID-19, started because of COVID-19, or not at all. The qualitative distinction in using telework before COVID-19 versus starting telework because of COVID-19 is substantively important. Teleworking before COVID-19 was primarily done by choice. In contrast, many workers who started telework because of COVID-19 were forced into it, as a result of 
lockdowns, government regulations, and other mandatory guidelines. Our data allow us to examine if this distinction is associated with subjective measures, such as overall satisfaction and perceived productivity gains.

\section{Background}

In the digital inequality literature, empirical studies have documented that user characteristics of early adopters differ systematically from those of late adopters (DiMaggio and Hargittai 2001). For example, Ono and Zavodny (2007) showed that early adopters of computers were more likely to be male, younger in age and highly educated. Income in particular is consistently associated with greater access to information and communication technologies (ICT), and the causation can go both ways (Robinson et al 2015). In other words, higher income is associated with ICT use, while ICT use in itself can lead to higher earnings.

The outbreak of the pandemic forced countries to take unprecedented measures to prevent widespread infection. As offices closed, people were forced to work from home or from another location. Already, we are witnessing the uneven distribution of telework access across and within countries (Robinson et al 2020). Some countries had higher access to telework than others. Likewise, some people gained access while others did not.

Access to telework is important because it allows people to continue working to sustain their income. But equally important, it is also a matter of public health, because people who cannot telework may have to risk their lives to work or commute to work. Monitoring access and usage of telework is a critical issue in both public policy and public health. Telework is already positioned as a new form of digital inequality. For example, a joint report issued by European-Commission and Eurofound (authored by Sostero et al in 2020 ) is entitled, "Teleworkability and the COVID-19 crisis: a new digital divide?" 


\section{Telework, Then and Now}

The concept of "telecommuting" dates back to 1975, when Nilles (1975) laid out the concept of "telecommunications-augmented decentralization," and the idea of using telecommunications technology to diffuse a traditional, centralized organization. He argued that telecommuting was an effective way to counter the pressures and inconveniences of contemporary working life, such as the urban sprawl, the separation of business and residential areas and overcrowded commutes. Although Nilles did not use the expression "telework" in his original paper, the basic tenets of telework, such as decreasing costs of telecommunications, rising power of computer processing, and the advantages of working from remote locations, are described in his writings.

The advancement of information communication technologies and the wider acceptance of telework in our lives have inspired researchers to study its basic features, such as access patterns, as well as social, psychological, and economic impacts. For example, Bailey and Kurland (2002) review the literature on telework research, and explain that access is higher among males, and that there is clear difference in occupation, along the lines of clerical versus professional workers. According to the U.S. Bureau of Labor Statistics (BLS 2019), seven percent of private-sector workers had access to flexible workplace benefits in 2019 but this number varies by wage levels, with higher wage workers gaining significantly higher access than lower wage workers. ${ }^{1}$ In the case of Finland, Luukinen (1996) explains that telecommuters tend to be male, independent professionals, high income, and highly educated.

Nonstandard workers, or those with precarious employment such as gig workers, are significantly less likely to telework (Adams-Prassl et al 2020). Even in the same occupation (e.g. IT professionals), attitude or self-perception of the job can generate large variations in teleworking (Mokhtarian and Salomon 1996). OECD (2020) also suggests

\footnotetext{
${ }^{1}$ The numbers do not necessarily correspond to the actual teleworking rate. Even if a company does not offer flexible workplace benefits, it is highly possible to take work home and work during the off-hours.
} 
that cultural and other factors potentially play an important role in variations in teleworking across countries.

In international comparisons, the European Union collects data of employed persons working from home as a percentage of the total employment among member countries. ${ }^{2}$ In 2019, the overall rate for working from home in the EU was 14.4 percent. This number varies significantly across member countries ranging from 1.1 percent in Bulgaria to 37.2 percent in Sweden. Sostero et. al. (2020) used Eurostat data and confirmed unequal access to telework by income levels, and across occupational lines among EU member states. For example, more than 40 percent of teachers and ICT professionals used telework, compared to less than 10 percent of personal service and sales workers. AdamsPrassl et al (2020) collected their own data of the working population in the U.S. and U.K., and find differences in the share of tasks that can be done from home by income levels and by occupation, with food preparation and serving, as well as farming, on the low end, and computer related and mathematical jobs on the high end of this spectrum. Similarly, Dingel and Neiman (2020) examined basic characteristics of jobs across different occupational categories to estimate the "teleworkability" index, and predict that 37 percent of jobs in the U.S. can be performed entirely at home. They apply the index to 85 other countries, and conclude that lower-income countries have a lower share of jobs that are "teleworkable." 3

International comparison of teleworking has been conducted by OECD (2020), EU, and other world organizations, but there are some caveats. ${ }^{4}$ First, in most reports, the data are collected from different sources, and at different time points, which makes consistent comparisons across countries difficult. And second, the studies have a particular geographic focus. Most are heavily skewed towards U.S. and European countries, and very few include Asian countries.

\footnotetext{
${ }^{2}$ Source is Eurostat, last accessed, December 2020. https://ec.europa.eu/eurostat/web/products-eurostatnews/

${ }^{3}$ See Sostero et al (2020) for similar analysis of "teleworkability" in the E.U. countries, and Boeri et al (2020) for similar analysis in Italy.

${ }^{4}$ See also study by Huws et al (1999) for international study of "teleworking and globalization."
} 
Telework and productivity is another important research theme. For example, before COVID-19, Bloom et. al. (2015) conducted a randomized telework experiment for call center employees at a Chinese company, and showed that there are moderate productivity increases from telework. In terms of productivity change after the COVID-19 outbreak, Morikawa (2020) conducted a survey in Japan in June 2020 and asked respondents to self-report the effect of telework on productivity. If productivity before COVID-19 is benchmarked at 100, the average self-reported productivity was 73.8 for those who started telework before COVID-19, and 59.3 for those who started telework for the first time after COVID-19 $(*$ the difference of 14.5 points was significant at the one percent level).

Researchers have also examined the effect of telework on subjective wellbeing. For example, Gajendran et.al. (2007) conducted a meta-analysis of the psychological effects of telecommuting on individuals, with respect to work satisfaction, productivity, turnover intention, stress, and perceived career prospects. They showed that telecommuting can improve job satisfaction, and lower turnover intentions, but it can also increase work stress. Raišiene et al (2020) showed that users with longer telecommuting experience were more likely to report a higher evaluation of benefits related to telecommuting.

\section{Research Questions}

What does the diffusion of telework look like across countries, and within countries? Who was more likely to telework before COVID-19, and after the outbreak of COVID-19? The eight countries in our sample provide an interesting mix in their responses to COVID-19, with some taking extremely strict measures for lockdown, e.g. China, versus others that took a more relaxed approach, e.g. Sweden. We will examine the extent to which the strictness of these lockdown measures may be related to teleworking at the country level. 
With respect to the timing of adoption among individuals, we expect to see systematic differences in user profiles before and after COVID-19, owing to the fact that many users were coerced into telework at the onset of the pandemic. We also take advantage of qualitative and attitudinal questions from the survey with respect to overall life satisfaction and perceived productivity gains from telework.

\section{Data}

We use cross-country microdata collected by the Nomura Research Institute (NRI). NRI conducted an online survey in July 2020, when the first wave of COVID-19 subsided somewhat in many countries and economic activity started to recover. The purpose of the survey is to investigate how digital services have progressed in people's lives through COVID-19 and the lockdowns associated with it, such as the use of online shopping, social media, online education, tele-medicine, etc., as well as the implementation of telework (or work from home). Data were collected in the following eight countries: U.S., U.K., Germany, Italy, Sweden, China, South Korea and Japan. Identical questionnaires were distributed in all countries at the same time, allowing us to make consistent comparisons across countries. The age of the respondents ranges from 15 to 69 . The starting sample size is 2,060 for each country, yielding a total of 16,480 observations. We used Stata 15 for our statistical analyses.

Reverse translation was used in designing the survey. The questionnaire was first created in Japanese and then translated into English. To ensure the quality of the English translation, the survey was retranslated from English back to Japanese to correct for subtle nuances. After creating the complete English version, the survey was translated into Chinese, Korean, German, Italian, and Swedish, and double-checked to ensure the quality.

Online surveys were conducted in eight countries during the second and third weeks of July 2020, followed by subsequent requests for responses by email. The target number of responses in each country was set to 2,000 . In order to resemble the population of each 
country, we set the target number of respondents by gender and age categories according to the population composition of each country. By considering the three percent buffer (i.e. 60 observations), we collected responses online until we reached 2,060 and fulfilled the target numbers of each gender and age category,

Questions about telework were asked only to those who were employed at the time of the survey. Thus, our starting sample consists of "teleworkable" persons, which excludes those who responded "full-time homemaker or domestic help", "student", or "unemployed." Because unemployment was high in some countries at the time of the survey (July 2020), we observe relatively higher numbers of unemployed respondents such as 28 percent in the U.S., which further decreased the starting sample size. The number of "teleworkable" persons ranges from 1,118 in the U.S. to 1,705 in China.

The dependent variable of main interest is teleworking. The survey asked, "We'd like to ask you about remote work (work from home)," followed by four possible responses: (i) Used telework before COVID-19, and continued to do so after the spread of the infection, (ii) Never used telework before COVID-19 - this was my first time to use it, (iii) Continued to go to my workplace because my work cannot be done remotely, and (iv) my workplace temporarily shut down - I stayed home. For simplicity, we refer to teleworkers as those who started (i) before COVID-19, and (ii) after COVID-19. ${ }^{5}$

As for the expression "telework," the most commonly used expression differed slightly from country to country, so we combine the terms "remote work", "telework", and "work from home" in the questionnaire to capture the broadest possible users. Specifically we used the expression "remote work (work from home)" in English, "Arbeit aus dem Home-Office (Telearbeit)" in German, "smart working (lavoro da casa)" in Italy, "remotearbete (jobba hemifrån)" in Swedish, "yuăn chéng bàn gōng (zài jiā bàn gōng)" in Chinese, "tellewokeu (jaetaeggeunmu)" in Hangul, and "terewāku (zaitaku kinmu) in Japanese.

${ }^{5}$ By "after COVID-19," we mean after the outbreak of COVID-19, not after COVID-19 has passed. 
The survey also asked several additional questions related to telework. These include the respondents' views on telework and productivity, difficulties of teleworking, and willingness to continue teleworking after COVID-19.

We note that due to the limitation of accessing rural areas of China and South Korea, respondents of these two countries are biased to urban residents (around 80 percent of respondents live in urban areas). Therefore, the results of China and South Korea more likely reflect the situation of urban areas rather than of the whole country. On the other hand, samples of other six countries represent the whole country in terms of urban/rural composition and age distribution. Another caveat is that education was not asked in the survey, because of the difficulty in controlling for educational differences across countries. We thus use income and occupation as a rough proxy for human capital. Descriptive statistics are shown in Appendix Table 1.

We control for demographic characteristics in the analyses. Age is a continuous linear variable ranging from 15 to 69 , in response to the question, "what is your age?" In order to maintain a consistent sample of the working population across countries, we excluded workers under the age of 20, which resulted in a 1.6 percent reduction in sample size. We examined alternative measures of age, such as age and its quadratic form, and cohort in 10 year categories, but the results did not differ significantly. We proceed with the linear specification of age because it produced the best fit. Gender was asked by the question, "what is your gender?" with possible responses that include male, female and "do not want to answer." Female is coded 1 if the respondent was female, and zero otherwise. Marital status was asked by the question, "what is your marital status?" with possible responses that include married (have a spouse), formerly married (divorced), formerly married (widowed), and unmarried. Marital status is coded 1 if the respondent was married, and zero otherwise. Family status was coded in response to the question, "what type of household do you live in?" with possible responses that include single-person household, couple-only household, couple and unmarried child(ren) household, single parent and 
unmarried child(ren) household, couple and married child(ren) household, household with three or more generations cohabiting together, and other. Family status is coded 1 to record the presence of children and/or elderly in the household, and zero otherwise. Urban status was recoded in response to the question, "which of the following three types of places describes where you live in?" with possible responses that include urban area, suburban area and countryside/rural area. Urban is coded 1 if respondent lived in urban areas and zero otherwise.

In the survey, income was asked by the question, "what is your own approximate monthly income (pre-tax)?" Income level is divided into ten categories based on each country's income distribution. We collapsed the income categories into quartiles per country, with the last category designated for missing income. We set the lowest income quartile as the reference (omitted) category.

The survey also asked for firm size by the question, "how many regular employees (excluding part-time workers, temporary workers, those working in other countries) are there at your job?" Possible responses are provided in 9 categories, with the smallest category designated to be less than 5 , and the last category designated for the public sector. We examined several specifications of firm size including its linear form, its logged form, and different categories of firm size. We settled for a five category measure of firm size because it captures best the non-parametric/ non-linear effects of firm size. The five firm size categories used in the analyses are: less than 5, 5 to 99,100 to 299,300 to 999,1000 or more, and government/ public sector.

The survey asked for fourteen distinct categories of occupation. We collapsed these into the following five categories: Office workers (omitted), manual and service workers, self-employed and family workers, managers and directors, and part-time workers. The original categories and the collapsed categories are shown in Appendix Table 2. 


\section{Results and Findings}

\section{The Current State of Telework}

Figure 1 shows the current state of telework in eight countries. Penetration rates range from a high of 75 percent in China to a low of 31 percent in Japan.

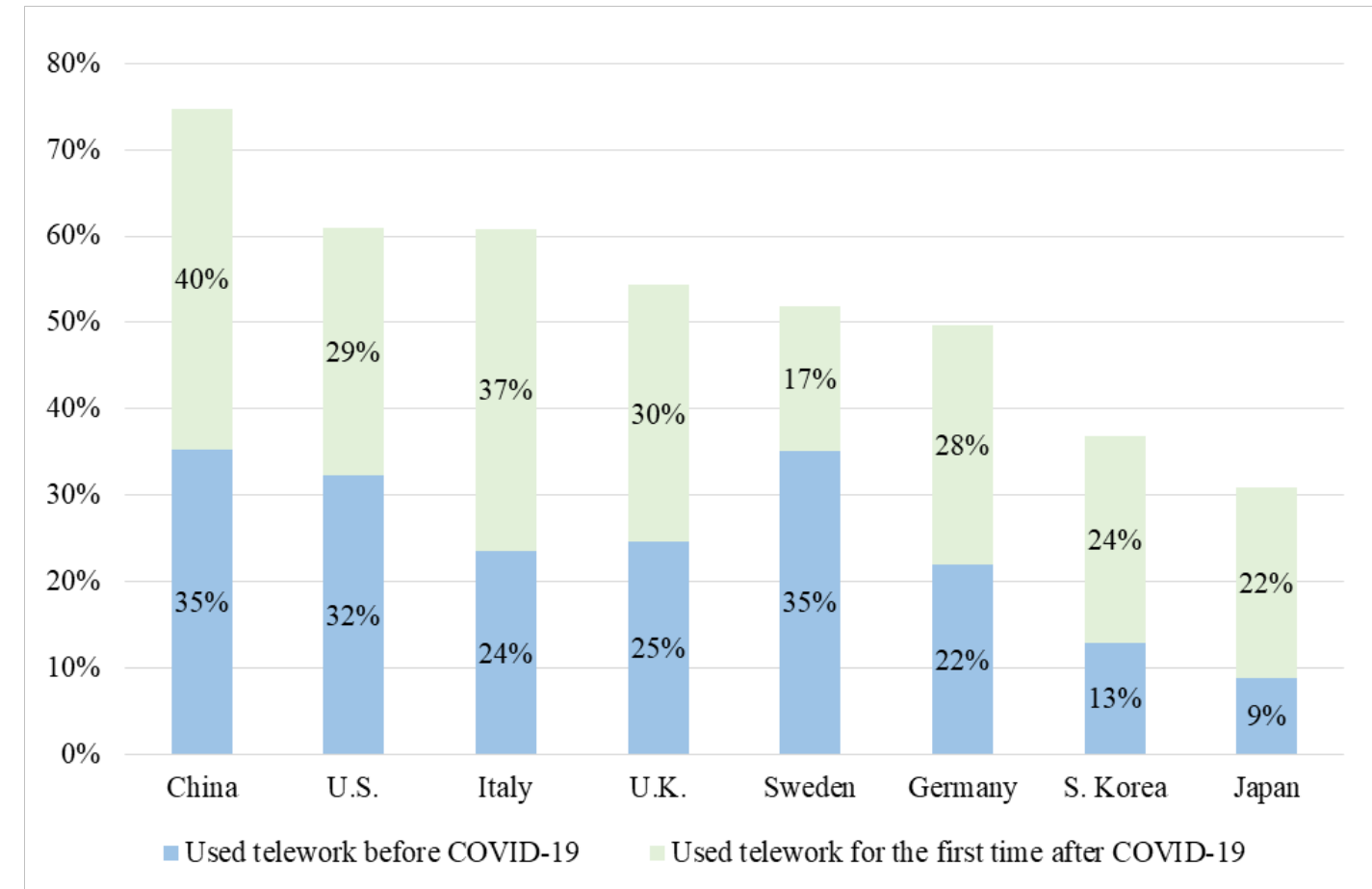

Figure 1. Teleworking in eight countries, before and after the outbreak of COVID19.

There is also variation in when the respondents started using telework. In the U.S., Sweden, and China, more than 30 percent used telework before COVID-19, while that number in S. Korea and Japan are only 13 percent and nine percent, respectively.

One possible explanation for the variation in teleworking across countries may be the stringency of the lockdown, i.e. how strictly was the lockdown policy enforced in the 
country? In countries with strict lockdowns, people were not allowed to leave their homes, in which case we would expect high teleworking, and vice versa.

To examine this relationship, we take advantage of the Coronavirus Government Response Tracker, which is similar to a stringency index of the lockdown during the COVID-19 outbreak. Higher numbers indicate stricter lockdowns and lower numbers indicate looser lockdowns. ${ }^{6}$ The data are collected daily by Oxford University, with a starting date of January 21, 2020. We used the data point for July 15, 2020, to match the date when the data were collected by NRI.

There is a clear positive correlation between lockdown stringency and teleworking, which is consistent with our expectation (Figure 2). The correlation between the two measures is 0.875 which is highly significant $(\mathrm{p}=0.0044)$. Teleworking is significantly higher in countries with strict lockdowns. China occupies the highest position on both measures, while the opposite is true for Japan, which occupies the lowest position on both measures.

\footnotetext{
${ }^{6}$ For particulars, see: https://www.bsg.ox.ac.uk/research/research-projects/coronavirus-governmentresponse-tracker
} 


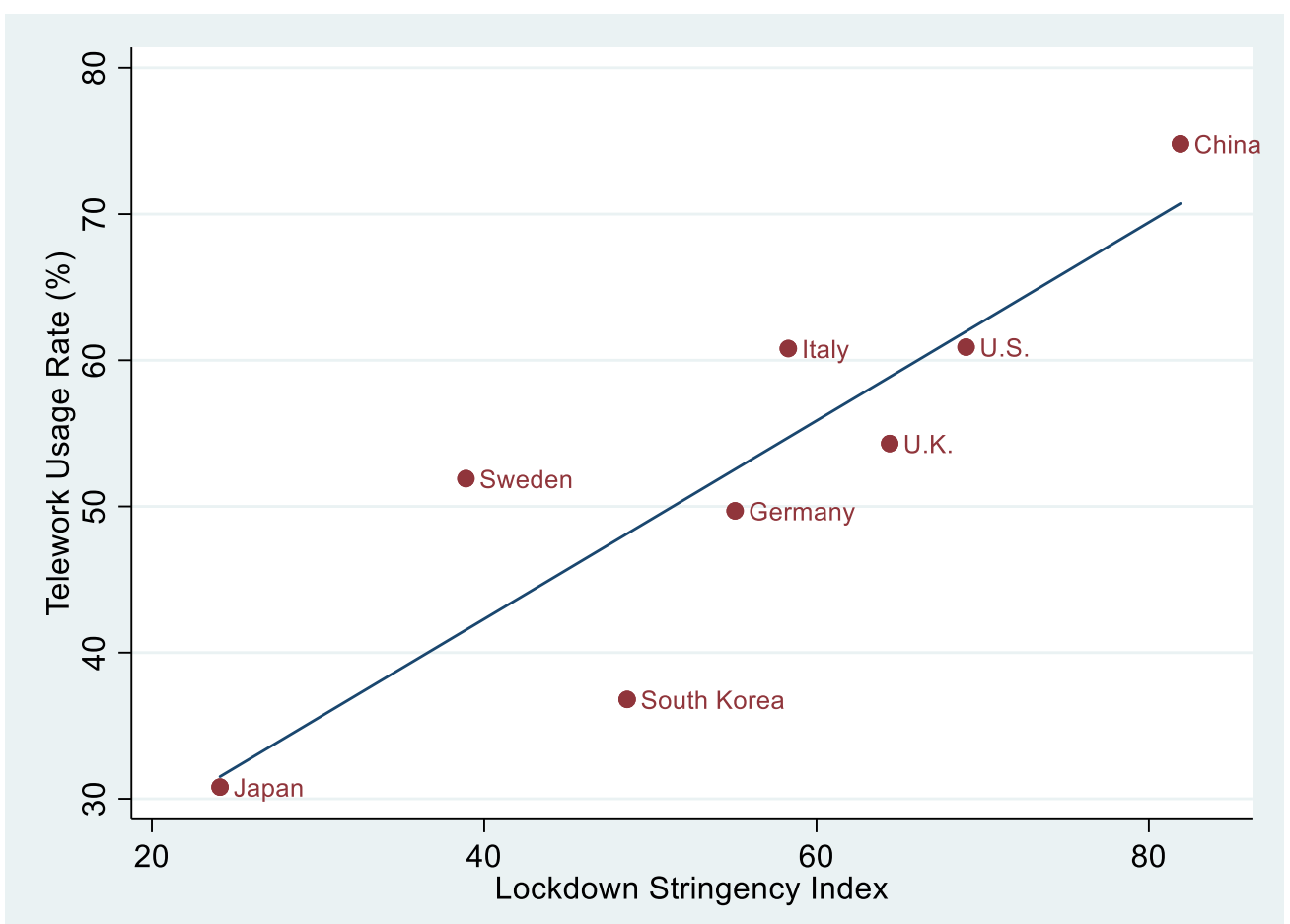

Figure 2. Teleworking rate and lockdown stringency (July 15, 2020).

Note. Stringency Index, Coronavirus Government Response Tracker, Oxford University.

\section{Teleworking Before COVID-19}

Table 1 shows logit coefficients about teleworking in the eight countries before the outbreak of COVID-19. Starting from the demographics, we observe that older persons were less likely to telework in the U.S., Italy, U.K. and Germany, but were more likely to do so in South Korea and Japan, while there is no association between age and teleworking in China and Sweden. Other demographic characteristics do not capture much of the variance in teleworking, with the possible exception of urban residents. Results show that teleworking was more common in the urban (versus rural) areas in China, U.S., Italy and Germany, while less common in South Korea. 
We observe some consistent patterns in teleworking and occupational categories across countries. In comparison to the reference category of office workers, manual and service workers were significantly less likely to report teleworking, with the exception of China and South Korea. ${ }^{7}$ In the U.S., U.K. and Japan, part-timers were significantly less likely to report teleworking, while more likely in China. We also find that self-employed persons were more likely to report teleworking before COVID-19 across the countries, with the exception of Sweden and Japan.

Teleworking is more commonly observed among those with higher income in China, U.S., U.K. and Sweden. In the other countries, we observe no association between income and teleworking.

Firm size differences show an overall pattern where the highest rate of teleworking is reported in the smallest category of less than five persons, with the exception of China. We note here that the omitted category is firms with less than five employees. It is thus plausible to assume that this category includes a large share of self-employed persons and independent business owners; some may in fact not even have offices. This is also consistent with the findings from occupational differences noted above; teleworking was more commonly observed among the self-employed. The results may also reflect differences in the way firms and labor market institutions are set up in these countries.

\footnotetext{
${ }^{7}$ Kawaguchi and Motegi (2020)'s study of remote work before covid-19 also finds that "workers engaged in routine, manual and interactive tasks" were less likely to work from home.
} 
Table 1. Logit Coefficients About Teleworking Before COVID-19.

\begin{tabular}{|c|c|c|c|c|c|c|c|c|}
\hline & $\begin{array}{c}(1) \\
\text { China } \\
\end{array}$ & $\begin{array}{r}(2) \\
\text { U.S. }\end{array}$ & $\begin{array}{c}\text { (3) } \\
\text { Italy }\end{array}$ & $\begin{array}{r}(4) \\
\text { U.K. }\end{array}$ & $\begin{array}{c}(5) \\
\text { Sweden } \\
\end{array}$ & $\begin{array}{c}(6) \\
\text { Germany } \\
\end{array}$ & $\begin{array}{c}(7) \\
\text { S. Korea } \\
\end{array}$ & $\begin{array}{c}(8) \\
\text { Japan }\end{array}$ \\
\hline \multicolumn{9}{|l|}{ [Demographics] } \\
\hline Age & $\begin{array}{l}-.004 \\
(.005)\end{array}$ & $\begin{array}{l}-.011 * \\
(.006)\end{array}$ & $\begin{array}{c}-.012 * * \\
(.006)\end{array}$ & $\begin{array}{l}-.011 * \\
(.005)\end{array}$ & $\begin{array}{l}-.003 \\
(.005)\end{array}$ & $\begin{array}{c}-.019 * * * \\
(.006)\end{array}$ & $\begin{array}{l}.017 * * \\
(.008)\end{array}$ & $\begin{array}{l}.017 * \\
(.009)\end{array}$ \\
\hline Female & $\begin{array}{l}-.094 \\
(.108)\end{array}$ & $\begin{array}{l}-.169 \\
(.153)\end{array}$ & $\begin{array}{c}-.456 * * * \\
(.146)\end{array}$ & $\begin{array}{l}-.064 \\
(.138)\end{array}$ & $\begin{array}{l}.045 \\
(.128)\end{array}$ & $\begin{array}{l}-.129 \\
(.153)\end{array}$ & $\begin{array}{l}-.103 \\
(.198)\end{array}$ & $\begin{array}{l}-.021 \\
(.245)\end{array}$ \\
\hline Married & $\begin{array}{l}.026 \\
(.188)\end{array}$ & $\begin{array}{c}.099 \\
(.164)\end{array}$ & $\begin{array}{l}-.005 \\
(.148)\end{array}$ & $\begin{array}{l}.125 \\
(.148)\end{array}$ & $\begin{array}{l}.212 * \\
(.128)\end{array}$ & $\begin{array}{l}.056 \\
(.164)\end{array}$ & $\begin{array}{l}-.282 \\
(.209)\end{array}$ & $\begin{array}{c}-.736 * * * \\
(.234)\end{array}$ \\
\hline Family & $\begin{array}{l}-.131 \\
(.128)\end{array}$ & $\begin{array}{l}-.212 \\
(.146)\end{array}$ & $\begin{array}{l}-.236 \\
(.148)\end{array}$ & $\begin{array}{l}-.209 \\
(.143)\end{array}$ & $\begin{array}{l}-.017 \\
(.129)\end{array}$ & $\begin{array}{l}-.202 \\
(.17)\end{array}$ & $\begin{array}{l}.155 \\
(.19)\end{array}$ & $\begin{array}{l}.378^{*} \\
(.22)\end{array}$ \\
\hline Urban & $\begin{array}{c}.524 * * * \\
(.162)\end{array}$ & $\begin{array}{l}.264^{*} \\
(.149)\end{array}$ & $\begin{array}{l}.245^{*} \\
(.147)\end{array}$ & $\begin{array}{c}.159 \\
(.138)\end{array}$ & $\begin{array}{l}.103 \\
(.124)\end{array}$ & $\begin{array}{l}.335^{* *} \\
(.142)\end{array}$ & $\begin{array}{c}-.531 * * * \\
(.206)\end{array}$ & $\begin{array}{l}.175 \\
(.211)\end{array}$ \\
\hline \multicolumn{9}{|c|}{ [Occupation: Omitted $=$ Office workers $]$} \\
\hline Manual/ service & $\begin{array}{l}-.198 \\
(.190)\end{array}$ & $\begin{array}{c}-.681 * * * \\
(.262)\end{array}$ & $\begin{array}{c}-1.403 * * * \\
(.319)\end{array}$ & $\begin{array}{c}-.774 * * * \\
(.223)\end{array}$ & $\begin{array}{c}-.954 * * * \\
(.169)\end{array}$ & $\begin{array}{c}-1.196^{* * *} \\
(.262)\end{array}$ & $\begin{array}{c}.238 \\
(.294)\end{array}$ & $\begin{array}{c}-1.605 * * * \\
(.393)\end{array}$ \\
\hline $\begin{array}{l}\text { Self-employed/ } \\
\text { family }\end{array}$ & $\begin{array}{c}.634 * * * \\
(.147)\end{array}$ & $\begin{array}{l}.365^{*} \\
(.203)\end{array}$ & $\begin{array}{c}.810 * * * \\
(.182)\end{array}$ & $\begin{array}{l}.490 * * \\
(.205)\end{array}$ & $\begin{array}{l}-.272 \\
(.177)\end{array}$ & $\begin{array}{l}.610 * * * \\
(.172)\end{array}$ & $\begin{array}{l}.999 * * * \\
(.241)\end{array}$ & $\begin{array}{l}.492 \\
(.427)\end{array}$ \\
\hline Managers/ directors & $\begin{array}{l}-.030 \\
(.142)\end{array}$ & $\begin{array}{l}.248 \\
(.205)\end{array}$ & $\begin{array}{l}.274 \\
(.251)\end{array}$ & $\begin{array}{l}.224 \\
(.171)\end{array}$ & $\begin{array}{l}.348 \\
(.238)\end{array}$ & $\begin{array}{l}.133 \\
(.242)\end{array}$ & $\begin{array}{l}.010 \\
(.316)\end{array}$ & $\begin{array}{l}.538 * \\
(.322)\end{array}$ \\
\hline Part-timers & $\begin{array}{l}.625 * * \\
(.299)\end{array}$ & $\begin{array}{l}-.442 * \\
(.264)\end{array}$ & $\begin{array}{l}.391 \\
(.254)\end{array}$ & $\begin{array}{c}-.687 * * \\
(.269)\end{array}$ & $\begin{array}{l}-.284 \\
(.224)\end{array}$ & $\begin{array}{l}-.436 \\
(.336)\end{array}$ & $\begin{array}{l}.194 \\
(.391)\end{array}$ & $\begin{array}{c}-.961 * * \\
(.464)\end{array}$ \\
\hline
\end{tabular}

Note. Standard errors are in parentheses. ${ }^{* * *} p<.01,{ }^{* *} p<.05,{ }^{*} p<.10$. 
Table 2. Logit Coefficients About Teleworking Before COVID-19 (continued).

\begin{tabular}{|c|c|c|c|c|c|c|c|c|}
\hline & $\begin{array}{c}(1) \\
\text { China } \\
\end{array}$ & $\begin{array}{l}(2) \\
\text { U.S. }\end{array}$ & $\begin{array}{l}(3) \\
\text { Italy }\end{array}$ & $\begin{array}{l}(4) \\
\text { U.K. }\end{array}$ & $\begin{array}{c}(5) \\
\text { Sweden }\end{array}$ & $\begin{array}{c}\text { (6) } \\
\text { Germany } \\
\end{array}$ & $\begin{array}{c}(7) \\
\text { S. Korea } \\
\end{array}$ & $\begin{array}{c}(8) \\
\text { Japan } \\
\end{array}$ \\
\hline \multicolumn{9}{|c|}{ [Income quartiles: Omitted = income quartile 1] } \\
\hline Income quartile 2 & $.425 * * *$ & .380 & .071 & -.072 & -.117 & -.110 & -.019 & .088 \\
\hline \multirow[t]{2}{*}{ Income quartile 3} & $.534 * * *$ & $.465^{*}$ & .174 & .148 & -.195 & -.287 & -.029 & -.149 \\
\hline & $(.157)$ & $(.240)$ & $(.250)$ & $(.245)$ & $(.229)$ & $(.234)$ & $(.287)$ & $(.412)$ \\
\hline \multirow[t]{2}{*}{ Income missing } & -.641 & -.167 & -.361 & .346 & .058 & -.331 & .388 & -.019 \\
\hline & $(1.133)$ & $(.567)$ & $(.357)$ & $(.358)$ & $(.268)$ & $(.352)$ & $(.824)$ & $(.418)$ \\
\hline \multicolumn{9}{|c|}{ [Firm size categories: Omitted $=$ Less than 5 employees $]$} \\
\hline 5 to 99 & .329 & $-1.086 * * *$ & $-.631 * * *$ & $-.909 * * *$ & $-1.422 * * *$ & $-1.135 * * *$ & $-.488 * *$ & $-.878 * *$ \\
\hline 300 to 999 & $(.313)$ & $(.280)$ & $(.261)$ & $(.260)$ & $(.236)$ & $(.260)$ & $(.396)$ & $(.531)$ \\
\hline \multirow[t]{2}{*}{1000 or more } & $.667^{*}$ & $-1.162 * * *$ & -.229 & $-.71 * * *$ & $-1.634 * * *$ & $-.836 * * *$ & -.053 & -.122 \\
\hline & $(.354)$ & $(.281)$ & $(.267)$ & $(.238)$ & $(.233)$ & $(.259)$ & $(.339)$ & $(.395)$ \\
\hline \multirow{2}{*}{$\begin{array}{l}\text { Government/ } \\
\text { public sector }\end{array}$} & .492 & $-1.081 *$ & $-1.64 * * *$ & $-.686^{* *}$ & $-1.409 * * *$ & -.442 & -.756 & - \\
\hline & $(.702)$ & $(.555)$ & $(.567)$ & $(.308)$ & $(.267)$ & $(.482)$ & $(.754)$ & \\
\hline \multirow[t]{2}{*}{ Constant } & $-1.621 * * *$ & .232 & -.297 & -.083 & $.856^{* *}$ & .526 & $-2.156 * * *$ & $-2.271 * * *$ \\
\hline & $(.390)$ & $(.428)$ & $(.365)$ & $(.403)$ & $(.357)$ & $(.396)$ & $(.487)$ & $(.620)$ \\
\hline Observations & 1,673 & 1,056 & 1,320 & 1,417 & 1,349 & 1,338 & 1,385 & 1,313 \\
\hline
\end{tabular}

Note. Standard errors are in parentheses. ${ }^{* * *} p<.01,{ }^{* *} p<.05,{ }^{*} p<.10$. 


\section{Teleworking After the Outbreak of COVID-19}

Table 2 shows logit coefficients associated with teleworking for the first time after the outbreak of COVID-19. Starting from the demographics, there is a clear pattern across countries that older workers were significantly less likely (and young workers more likely) to telework for the first time after COVID-19, with the exception of Sweden. Telework for the first time was more common in urban areas in Sweden, South Korea and Japan, while less common in China.

With respect to occupational categories, manual and service workers were significantly less likely to telework in all countries (compared to the reference category of office workers). The signs for self-employed persons have now reversed from plus to minus across the countries, with the exception of Sweden. Even more clearly, we can observe that part-timers were significantly less likely to telework after the outbreak of COVID-19, compared to the occupation category of office workers.

With respect to firm size, there is a general pattern of increase in first-time teleworkers among the larger firms, with the exception of the U.K. and South Korea. We observe that the signs have now reversed in the U.S., Italy, Germany and Japan. In these countries, teleworking was more commonly observed in smaller establishments before COVID-19; after the outbreak, it was more commonly observed in larger establishments. In Japan, teleworking in the government sector was nil before the outbreak (as shown by the empty cell in Table 1), but achieved high penetration after the outbreak (as shown in Table 2).

These results suggest that COVID-19 was an inflection point for the diffusion of telework into the larger business establishments. Telework was no longer confined to independent business owners and the self-employed, but a practice that became more common in the wider business community. 
Table 2: Logit Coefficients About Teleworking for the First Time After Outbreak of COVID-19.

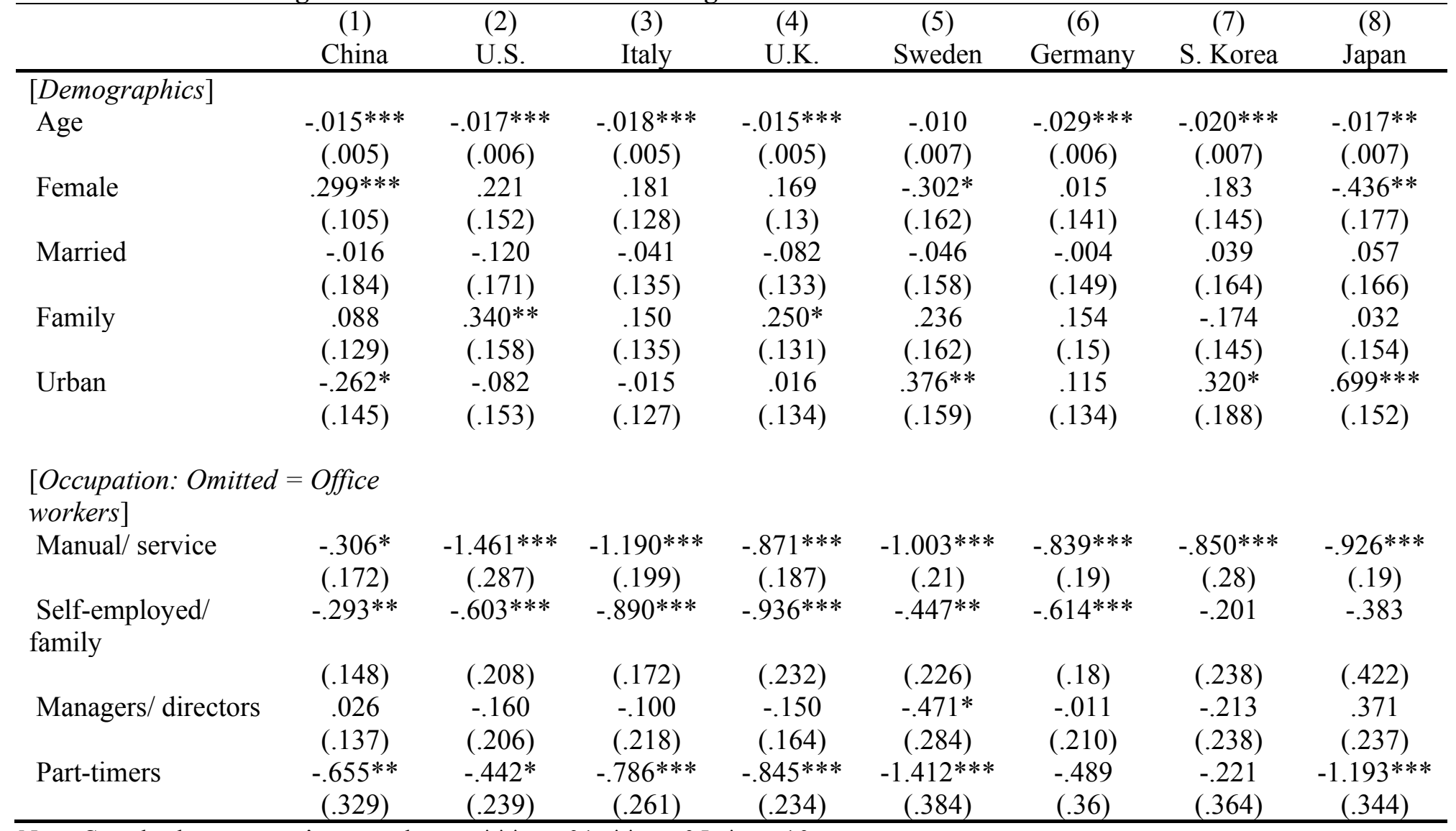

Note. Standard errors are in parentheses. ${ }^{* * *} p<.01,{ }^{* *} p<.05,{ }^{*} p<.10$. 
Table 2: Logit Coefficients About Teleworking for the First Time After Outbreak of COVID-19 (continued).

\begin{tabular}{|c|c|c|c|c|c|c|c|c|}
\hline & $\begin{array}{c}(1) \\
\text { China }\end{array}$ & $\begin{array}{l}(2) \\
\text { U.S. }\end{array}$ & $\begin{array}{l}\text { (3) } \\
\text { Italy }\end{array}$ & $\begin{array}{r}(4) \\
\text { U.K. }\end{array}$ & $\begin{array}{c}(5) \\
\text { Sweden }\end{array}$ & $\begin{array}{c}(6) \\
\text { Germany }\end{array}$ & $\begin{array}{c}(7) \\
\text { S. Korea }\end{array}$ & $\begin{array}{c}(8) \\
\text { Japan }\end{array}$ \\
\hline \multicolumn{9}{|c|}{ [Income quartiles: Omitted = income quartile 1] } \\
\hline Income quartile 2 & .194 & $-.506^{* *}$ & $.387 * *$ & .298 & $-.484 *$ & .145 & .375 & .475 \\
\hline \multirow[t]{2}{*}{ Income quartile 3} & .107 & -.356 & .325 & $.444 *$ & .054 & .377 & $.785 * * *$ & $.851 * * *$ \\
\hline & $(.150)$ & $(.230)$ & $(.229)$ & $(.234)$ & $(.275)$ & $(.245)$ & $(.236)$ & $(.308)$ \\
\hline \multirow[t]{2}{*}{ Income missing } & - & -.249 & $.643 * *$ & .182 & .014 & -.410 & - & .270 \\
\hline & & $(.564)$ & $(.275)$ & $(.349)$ & $(.353)$ & $(.417)$ & & $(.352)$ \\
\hline \multicolumn{9}{|c|}{ [Firm size categories: Omitted $=$ Less than 5 employees $]$} \\
\hline 5 to 99 & $.867 * *$ & $.740 * *$ & $.440 * *$ & -.172 & .319 & $.985 * * *$ & -.034 & .573 \\
\hline 300 to 999 & $(.361)$ & $(.309)$ & $(.243)$ & $(.273)$ & $(.347)$ & $(.317)$ & $(.278)$ & $(.397)$ \\
\hline \multirow[t]{2}{*}{1000 or more } & $.748 *$ & $.684 * *$ & $.506 * *$ & -.069 & .417 & $1.087 * * *$ & .174 & $1.141 * * *$ \\
\hline & $(.399)$ & $(.309)$ & $(.245)$ & $(.250)$ & $(.340)$ & $(.315)$ & $(.271)$ & $(.381)$ \\
\hline \multirow{2}{*}{$\begin{array}{l}\text { Government/ } \\
\text { public sector }\end{array}$} & -.185 & $1.419 * * *$ & $1.216^{* * *}$ & -.170 & .490 & $1.113 * *$ & -.114 & $1.453 * * *$ \\
\hline & $(.862)$ & $(.516)$ & $(.325)$ & $(.325)$ & $(.380)$ & $(.495)$ & $(.477)$ & $(.504)$ \\
\hline \multirow[t]{2}{*}{ Constant } & $-.728^{*}$ & -.349 & -.188 & -.274 & $-1.189 * *$ & $-.787 *$ & $-1.023 * *$ & $-1.798 * * *$ \\
\hline & $(.409)$ & $(.443)$ & $(.345)$ & $(.378)$ & $(.462)$ & $(.436)$ & $(.431)$ & $(.581)$ \\
\hline Observations & 1,669 & 1,056 & 1,320 & 1,417 & 1,349 & 1,338 & 1,375 & 1,364 \\
\hline
\end{tabular}

Note. Standard errors are in parentheses. ${ }^{* * *} p<.01, * * p<.05, * p<.10$. 


\section{Work-Related Experiences and the Future of Telework}

One of the benefits of telework is that it allows its users flexibility in choosing a location to work. Even before the COVID-19 crisis, HR specialists and scholars viewed telework as an effective way to increase control and autonomy among the workers, and as a means to improve work-family balance. Telework fits into the positive cycle of motivation, happiness and productivity (Ono 2019; Oswald et al 2015; Roscigno et al 2018): enabling autonomy and control to increase work motivation and life satisfaction, which ultimately increases productivity.

We now examine the extent to which telework may (or may not) be associated with such benefits. Although the data are not set up to examine the cycle systematically, we can see, at least in a limited way, how telework is associated with each stage of the cycle. In this analyses and hereafter, we used a pooled sample of respondents in all eight countries. In all regressions, we control for country-specific fixed effects. In Table 3, the first column shows the results of OLS regressions about how teleworking correlates with life satisfaction. The dependent variable ranges from $0=$ completely unsatisfied to $10=$ completely satisfied.

In addition, we ran regression models examining happiness and fulfillment, which were also asked in the survey, but the results were not substantively different, and are not reported here. In this analysis, the omitted category is respondents who did not telework. Compared to this baseline group, we see a clear difference in the coefficients between users who started telework before and after COVID-19. Users in the former reported significantly higher satisfaction; users in the latter reported no change in life satisfaction (compared to the benchmark). These results are consistent with those reported by Raišiene et al (2020); compared to users who experienced telework before the lockdown, those who started after the lockdown were more likely to provide a negative or neutral assessment of telework. 
Table 3: OLS and Ordered Logit Regressions Examining the Relationship of Teleworking with Life Satisfaction and Perceived Productivity.

\begin{tabular}{|c|c|c|}
\hline & $\begin{array}{c}\text { Full sample } \\
O L S \\
(1) \\
\text { Life satisfaction }\end{array}$ & $\begin{array}{c}\text { Teleworkers only } \\
\text { Ordered Logit } \\
(2) \\
\text { Productivity }\end{array}$ \\
\hline [Omitted: Did not telework] & - & - \\
\hline Teleworked before COVID-19 & $\begin{array}{l}.252 * * * \\
(.053)\end{array}$ & [omitted $]$ \\
\hline $\begin{array}{l}\text { Teleworked for the first time } \\
\text { after outbreak of COVID-19 }\end{array}$ & $\begin{array}{l}.062 \\
(.050)\end{array}$ & $\begin{array}{c}-.225 * * * \\
(.051)\end{array}$ \\
\hline [Demographics] & & \\
\hline Age & $\begin{array}{c}-.006^{* * * *} \\
(.002)\end{array}$ & $\begin{array}{l}.001 \\
(.002)\end{array}$ \\
\hline Female & $\begin{array}{c}.147 * * * \\
(.042)\end{array}$ & $\begin{array}{l}.115 * * \\
(.051)\end{array}$ \\
\hline Married & $\begin{array}{l}.842^{* * *} \\
(.046)\end{array}$ & $\begin{array}{l}-.073 \\
(.058)\end{array}$ \\
\hline Family & $\begin{array}{c}-.099 * * \\
(.043)\end{array}$ & $\begin{array}{l}.080 \\
(.054)\end{array}$ \\
\hline Urban & $\begin{array}{l}.167 * * * \\
(.044)\end{array}$ & $\begin{array}{l}.049 \\
(.054)\end{array}$ \\
\hline \multicolumn{3}{|c|}{$[$ Occupation: Omitted $=$ Office workers $]$} \\
\hline Manual/ service & $\begin{array}{c}-.192 * * * \\
(.059)\end{array}$ & $\begin{array}{c}-.319 * * * \\
(.086)\end{array}$ \\
\hline Self-employed/ family & $\begin{array}{l}-.102 * \\
(.061)\end{array}$ & $\begin{array}{c}-.312 * * * \\
(.072)\end{array}$ \\
\hline Managers/ directors & $\begin{array}{l}.147^{* *} \\
(.065)\end{array}$ & $\begin{array}{l}.076 \\
(.072)\end{array}$ \\
\hline Part-timers & $\begin{array}{l}.084 \\
(.078)\end{array}$ & $\begin{array}{l}-.118 \\
(.108)\end{array}$ \\
\hline
\end{tabular}

Note. Standard errors are in parentheses. ${ }^{* * *} p<.01,{ }^{* *} p<.05,{ }^{*} p<.10$. 
Table 3: OLS and Logit Regressions Examining the Relationship of Teleworking and Life Satisfaction and Perceived Productivity (continued).

\begin{tabular}{|c|c|c|}
\hline & $\begin{array}{c}\text { Full sample } \\
\text { OLS }\end{array}$ & $\begin{array}{c}\text { Teleworkers only } \\
\text { Ordered Logit }\end{array}$ \\
\hline & $\begin{array}{c}(1) \\
\text { Life satisfactions } \\
\end{array}$ & $\begin{array}{c}(2) \\
\text { Productivity } \\
\end{array}$ \\
\hline \multicolumn{3}{|c|}{ [Income quartiles: Omitted = income quartile 1] } \\
\hline Income quartile 2 & $\begin{array}{l}.375^{* * * *} \\
(.061)\end{array}$ & $\begin{array}{l}.021 \\
(.077)\end{array}$ \\
\hline Income quartile 3 & $\begin{array}{l}.739 * * * \\
(.065)\end{array}$ & $\begin{array}{l}.131 \\
(.081)\end{array}$ \\
\hline Income quartile 4 & $\begin{array}{c}1.112 * * * \\
(.071)\end{array}$ & $\begin{array}{l}.135 \\
(.084)\end{array}$ \\
\hline Income missing & $\begin{array}{l}.551 * * * \\
(.102)\end{array}$ & $\begin{array}{l}.266^{*} \\
(.136)\end{array}$ \\
\hline \multicolumn{3}{|c|}{ [Firm size categories: Omitted $=$ Less than 5 employees $]$} \\
\hline 5 to 99 & $\begin{array}{l}.089 \\
(.067)\end{array}$ & $\begin{array}{l}-.082 \\
(.085)\end{array}$ \\
\hline 100 to 299 & $\begin{array}{l}.150^{*} \\
(.081)\end{array}$ & $\begin{array}{l}.149 \\
(.101)\end{array}$ \\
\hline 300 to 999 & $\begin{array}{l}.226 * * * \\
(.081)\end{array}$ & $\begin{array}{l}.073 \\
(.100)\end{array}$ \\
\hline 1000 or more & $\begin{array}{l}.140^{*} \\
(.081)\end{array}$ & $\begin{array}{l}.201 * * \\
(.101)\end{array}$ \\
\hline Government/ public sector & $\begin{array}{l}.088 \\
(.120)\end{array}$ & $\begin{array}{l}.028 \\
(.144)\end{array}$ \\
\hline
\end{tabular}

Note. Standard errors are in parentheses. ${ }^{* * *} \mathrm{p}<.01,{ }^{* *} \mathrm{p}<.05,{ }^{*} \mathrm{p}<.10$. 
Table 3: OLS and Logit Regressions Examining the Relationship of Teleworking and Life Satisfaction and Perceived Productivity (continued).

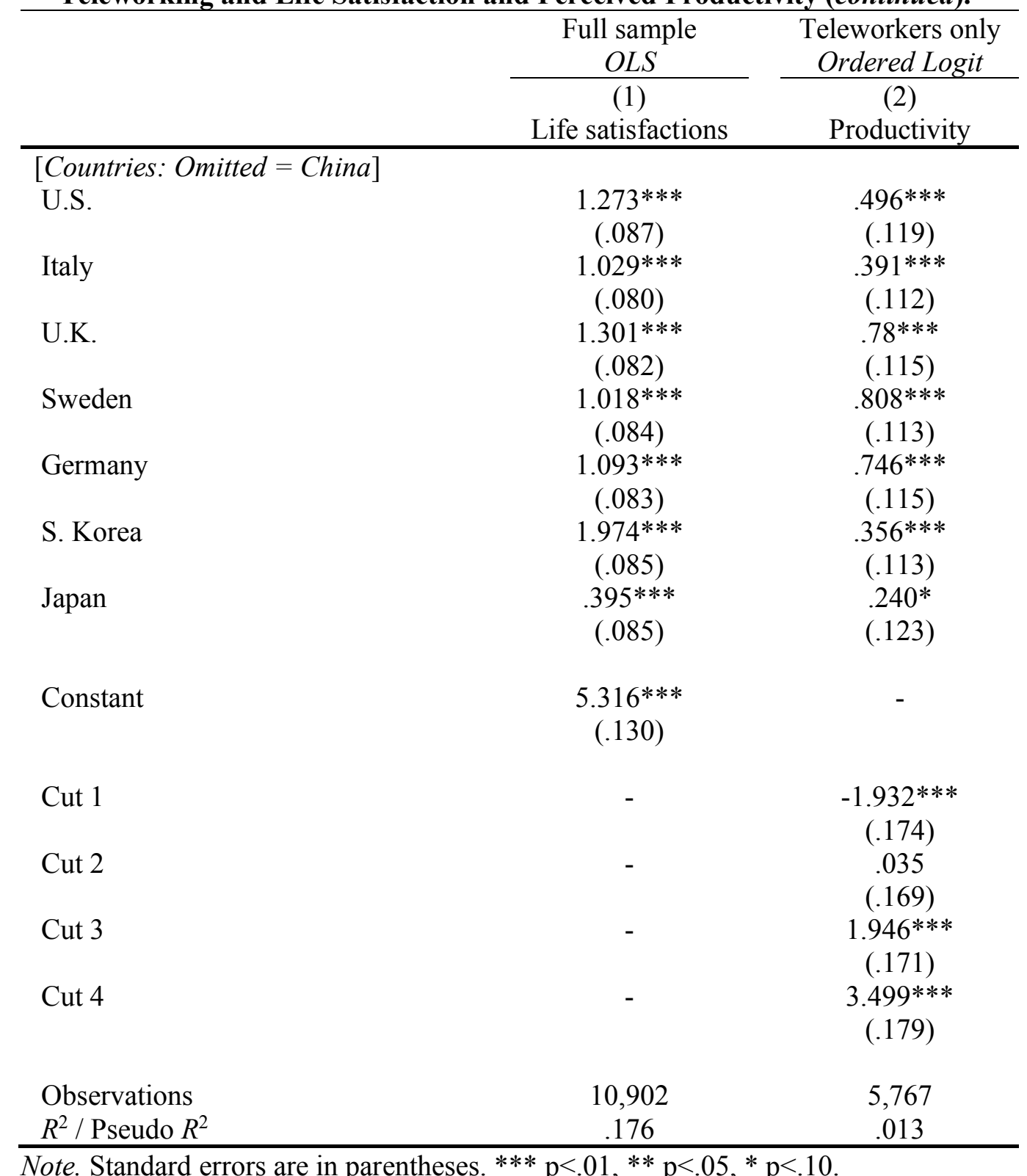


Column 2 shows the results of ordered logit estimations in response to the question which asked respondents about their work productivity during telework. Possible responses range from $1=$ substantially reduced to $5=$ substantially better. The current sample is restricted to teleworkers only.

The results show that respondents who started telework for the first time after COVID-19 were more likely to report that their productivity went down because of telework, relative to those that started telework before COVID-19.

These varying responses in life satisfaction and perceived productivity changes most likely reflect qualitative distinctions in how telework was introduced before and after COVID-19. Those who started using telework before COVID-19 presumably did so by choice, but the same cannot be said for those who started after the outbreak. Rather, it is reasonable to assume that there were at least some in the latter group who were forced into telework involuntarily through government order, which may have led to their lower satisfaction and perceptions of lower productivity. 8

In our final analysis, we estimated multinomial logit equations to examine the likelihood of using telework after the outbreak of COVID-19, in response to the question: Do you want to telework in the future? In Table 4, the columns show the dependent variables in comparison to the omitted reference category of not using telework after COVID-19.

In the analysis with the full sample, we can see that both groups of teleworkers have a greater likelihood of teleworking after COVID-19, compared to the reference group of those that did not telework. In other words, people who experience telework are more likely to report that they want to continue to telework. The results also show that those who started

\footnotetext{
${ }^{8}$ See also Bailey and Kurland (2002), who review the literature on empirical findings related to selfreported outcomes of telework, and find mixed or little evidence of its positive effects on job satisfaction and productivity.
} 
telework because of COVID-19 are more likely to respond that they want to continue teleworking only as an emergency measure and less so on an everyday basis, while the opposite is true for those who started telework before COVID-19.

Table 4: Multinomial Logit Equations Examining the Likelihood of Using Telework After COVID-19 (In Comparison to the Reference Category of not Teleworking After COVID-19).

\begin{tabular}{|c|c|c|c|c|}
\hline & \multicolumn{2}{|c|}{ Full sample } & \multicolumn{2}{|c|}{ Teleworkers only } \\
\hline & $\begin{array}{c}\text { (1) } \\
\text { Only as an } \\
\text { emergency } \\
\text { measure }\end{array}$ & $\begin{array}{c}(2) \\
\text { Continue } \\
\text { in } \\
\text { everyday } \\
\text { life } \\
\end{array}$ & $\begin{array}{c}(3) \\
\text { Only as an } \\
\text { emergency } \\
\text { measure }\end{array}$ & $\begin{array}{c}(4) \\
\text { Continue } \\
\text { in } \\
\text { everyday } \\
\text { life } \\
\end{array}$ \\
\hline [Omitted: Did not telework] & \multicolumn{2}{|c|}{ - } & \multicolumn{2}{|c|}{-} \\
\hline Teleworking before COVID-19 & $\begin{array}{c}.849^{* * *} \\
(.070)\end{array}$ & $\begin{array}{c}1.745^{* * *} * \\
(.066)\end{array}$ & \multicolumn{2}{|c|}{ [omitted $]$} \\
\hline Teleworking for the first time & $1.103 * * *$ & $.981 * * *$ & $.231 * * *$ & $-.786 * * *$ \\
\hline & $(.06)$ & $(.065)$ & $(.072)$ & $(.075)$ \\
\hline Perceived productivity & - & - & $\begin{array}{c}.151 * * * \\
(.036)\end{array}$ & $\begin{array}{c}.664 * * * \\
(.038)\end{array}$ \\
\hline \multicolumn{5}{|l|}{ [Demographics] } \\
\hline Age & $\begin{array}{c}-.006 * * * \\
(.002)\end{array}$ & $\begin{array}{c}.007 * * * \\
(.002)\end{array}$ & $\begin{array}{c}.008 * * * \\
(.003)\end{array}$ & $\begin{array}{c}.026 * * * \\
(.003)\end{array}$ \\
\hline Female & $\begin{array}{l}.093 * \\
(.052)\end{array}$ & $\begin{array}{c}.251 * * * \\
(.053)\end{array}$ & $\begin{array}{c}.154 * * \\
(.07)\end{array}$ & $\begin{array}{c}.363 * * * \\
(.074)\end{array}$ \\
\hline Married & $\begin{array}{l}-.069 \\
(.058)\end{array}$ & $\begin{array}{c}-.198 * * * \\
(.057)\end{array}$ & $\begin{array}{l}-.151 * \\
(.082)\end{array}$ & $\begin{array}{c}-.200 * * \\
(.083)\end{array}$ \\
\hline Family & $\begin{array}{c}.283 * * * \\
(.054)\end{array}$ & $\begin{array}{l}-.044 \\
(.054)\end{array}$ & $\begin{array}{l}.29 * * * \\
(.074)\end{array}$ & $\begin{array}{l}-.084 \\
(.076)\end{array}$ \\
\hline Urban & $\begin{array}{r}.063 \\
(.055) \\
\end{array}$ & $\begin{array}{c}-.089 \\
(.055) \\
\end{array}$ & $\begin{array}{l}-.008 \\
(.076) \\
\end{array}$ & $\begin{array}{c}-.199 * * * \\
(.077)\end{array}$ \\
\hline
\end{tabular}

Note. Standard errors are in parentheses. ${ }^{* * *} p<.01,{ }^{* *} p<.05, * p<.10$. 
Table 4: Multinomial Logit Equations Examining the Likelihood of Using Telework After COVID-19 (In Comparison to the Reference Category of not Teleworking After COVID-19, continued).

\begin{tabular}{|c|c|c|c|c|}
\hline & \multicolumn{2}{|c|}{ Full sample } & \multicolumn{2}{|c|}{ Teleworkers only } \\
\hline & $\begin{array}{c}(1) \\
\text { Only as an } \\
\text { emergency } \\
\text { measure }\end{array}$ & $\begin{array}{c}(2) \\
\text { Continue in } \\
\text { everyday } \\
\text { life }\end{array}$ & $\begin{array}{c}(3) \\
\text { Only as an } \\
\text { emergency } \\
\text { measure }\end{array}$ & $\begin{array}{c}\text { (4) } \\
\text { Continue in } \\
\text { everyday } \\
\text { life }\end{array}$ \\
\hline \multicolumn{5}{|c|}{ [Occupation: Omitted $=$ Office workers] } \\
\hline Manual/ service & $\begin{array}{c}-.482 * * * \\
(.076)\end{array}$ & $\begin{array}{c}-.554 * * * \\
(.076)\end{array}$ & $\begin{array}{c}-.260 * * \\
(.116)\end{array}$ & $\begin{array}{c}-.433 * * * \\
(.124)\end{array}$ \\
\hline Self-employed/ family & $\begin{array}{c}-.365^{* * *} \\
(.075)\end{array}$ & $\begin{array}{c}-.661 * * * \\
(.078)\end{array}$ & $\begin{array}{c}-.432 * * * \\
(.097)\end{array}$ & $\begin{array}{c}-.747 * * * \\
(.103)\end{array}$ \\
\hline Managers/ directors & $\begin{array}{l}-.086 \\
(.078)\end{array}$ & $\begin{array}{c}-.185^{* *} \\
(.081)\end{array}$ & $\begin{array}{l}.038 \\
(.097)\end{array}$ & $\begin{array}{c}-.216^{* *} \\
(.104)\end{array}$ \\
\hline Part-timers & $\begin{array}{c}-.199 * * \\
(.098)\end{array}$ & $\begin{array}{c}-.498 * * * \\
(.097)\end{array}$ & $\begin{array}{c}-.325 * * \\
(.153)\end{array}$ & $\begin{array}{c}-.810^{* * *} \\
(.157)\end{array}$ \\
\hline \multicolumn{5}{|c|}{ [Income quartiles: Omitted $=$ income quartile 1] } \\
\hline Income quartile 2 & $\begin{array}{c}.022 \\
(.076)\end{array}$ & $\begin{array}{l}-.073 \\
(.076)\end{array}$ & $\begin{array}{l}-.039 \\
(.106)\end{array}$ & $\begin{array}{l}.041 \\
(.112)\end{array}$ \\
\hline Income quartile 3 & $\begin{array}{l}.100 \\
(.081)\end{array}$ & $\begin{array}{l}-.072 \\
(.082)\end{array}$ & $\begin{array}{l}.048 \\
(.112)\end{array}$ & $\begin{array}{l}.162 \\
(.119)\end{array}$ \\
\hline Income quartile 4 & $\begin{array}{l}.165^{*} \\
(.087)\end{array}$ & $\begin{array}{l}-.106 \\
(.089)\end{array}$ & $\begin{array}{l}.127 \\
(.114)\end{array}$ & $\begin{array}{l}-.011 \\
(.124)\end{array}$ \\
\hline Income missing & $\begin{array}{l}.085 \\
(.135)\end{array}$ & $\begin{array}{l}.066 \\
(.123)\end{array}$ & $\begin{array}{l}.110 \\
(.207)\end{array}$ & $\begin{array}{c}.074 \\
(.198)\end{array}$ \\
\hline \multicolumn{5}{|c|}{ [Firm size categories: Omitted $=$ Less than 5 employees $]$} \\
\hline 5 to 99 & $\begin{array}{l}-.083 \\
(.087)\end{array}$ & $\begin{array}{c}-.610 * * * \\
(.082)\end{array}$ & $\begin{array}{c}-.369^{* * *} \\
(.128)\end{array}$ & $\begin{array}{c}-1.011^{* * *} \\
(.122)\end{array}$ \\
\hline 100 to 299 & $\begin{array}{l}-.008 \\
(.102)\end{array}$ & $\begin{array}{c}-.481 * * * \\
(.100)\end{array}$ & $\begin{array}{l}-.185 \\
(.145)\end{array}$ & $\begin{array}{c}-.947 * * * \\
(.145)\end{array}$ \\
\hline 300 to 999 & $\begin{array}{l}.112 \\
(.102)\end{array}$ & $\begin{array}{c}-.393 * * * \\
(.100)\end{array}$ & $\begin{array}{l}.070 \\
(.145)\end{array}$ & $\begin{array}{c}-.639 * * * \\
(.144)\end{array}$ \\
\hline 1000 or more & $\begin{array}{c}-.08 \\
(.106)\end{array}$ & $\begin{array}{l}-.074 \\
(.096)\end{array}$ & $\begin{array}{l}-.001 \\
(.154)\end{array}$ & $\begin{array}{l}-.235 \\
(.145)\end{array}$ \\
\hline Government/ public sector & $\begin{array}{c}.077 \\
(.155) \\
\end{array}$ & $\begin{array}{r}-.113 \\
(.142) \\
\end{array}$ & $\begin{array}{r}.176 \\
(.222) \\
\end{array}$ & $\begin{array}{r}-.263 \\
(.211) \\
\end{array}$ \\
\hline
\end{tabular}

Note. Standard errors are in parentheses. ${ }^{* * *} \mathrm{p}<.01,{ }^{* *} \mathrm{p}<.05,{ }^{*} \mathrm{p}<.10$. 
Table 4: Multinomial Logit Equations Examining the Likelihood of Using Telework After COVID-19 (In Comparison to the Reference Category of not Teleworking After COVID-19, continued).

\begin{tabular}{|c|c|c|c|c|}
\hline & \multicolumn{2}{|c|}{ Full sample } & \multicolumn{2}{|c|}{ Teleworkers only } \\
\hline & $\begin{array}{c}(1) \\
\text { Only as an } \\
\text { emergency } \\
\text { measure }\end{array}$ & $\begin{array}{c}(2) \\
\text { Continue in } \\
\text { everyday } \\
\text { life }\end{array}$ & $\begin{array}{c}(3) \\
\text { Only as an } \\
\text { emergency } \\
\text { measure }\end{array}$ & $\begin{array}{c}(4) \\
\text { Continue in } \\
\text { everyday } \\
\text { life }\end{array}$ \\
\hline \multicolumn{5}{|c|}{$[$ Countries: Omitted $=$ China $]$} \\
\hline U.S. & $\begin{array}{l}.062 \\
(.110)\end{array}$ & $\begin{array}{l}-.169 \\
(.107)\end{array}$ & $\begin{array}{l}-.378^{* *} \\
(.174)\end{array}$ & $\begin{array}{c}-.975 * * * \\
(.174)\end{array}$ \\
\hline Italy & $\begin{array}{c}-.277 * * * \\
(.106)\end{array}$ & $\begin{array}{l}-.077 \\
(.096)\end{array}$ & $\begin{array}{c}-.737 * * * \\
(.173)\end{array}$ & $\begin{array}{c}-.725 * * * \\
(.164)\end{array}$ \\
\hline U.K. & $\begin{array}{c}-.389 * * * \\
(.108)\end{array}$ & $\begin{array}{c}-.423 * * * \\
(.101)\end{array}$ & $\begin{array}{c}-.622 * * * \\
(.175)\end{array}$ & $\begin{array}{c}-.997 * * * \\
(.170)\end{array}$ \\
\hline Sweden & $\begin{array}{l}-.146 \\
(.106)\end{array}$ & $\begin{array}{c}-.363 * * * \\
(.103)\end{array}$ & $\begin{array}{c}-.618^{* * *} \\
(.169)\end{array}$ & $\begin{array}{c}-1.199 * * * \\
(.167)\end{array}$ \\
\hline Germany & $\begin{array}{l}-.012 \\
(.106)\end{array}$ & $\begin{array}{c}-.291 * * * \\
(.101)\end{array}$ & $\begin{array}{c}-.483 * * * \\
(.175)\end{array}$ & $\begin{array}{c}-1.089 * * * \\
(.171)\end{array}$ \\
\hline S. Korea & $\begin{array}{l}.144 \\
(.104)\end{array}$ & $\begin{array}{c}-.680 * * * \\
(.111)\end{array}$ & $\begin{array}{l}-.190 \\
(.164)\end{array}$ & $\begin{array}{c}-1.431 * * * \\
(.173)\end{array}$ \\
\hline Japan & $\begin{array}{c}1.071 * * * \\
(.104)\end{array}$ & $\begin{array}{c}.345^{* * *} \\
(.108)\end{array}$ & $\begin{array}{c}.540 * * * \\
(.185)\end{array}$ & $\begin{array}{c}-.580 * * * \\
(.194)\end{array}$ \\
\hline Constant & $\begin{array}{c}-1.021 * * * \\
(.164)\end{array}$ & $\begin{array}{c}-.668 * * * \\
(.160)\end{array}$ & $\begin{array}{c}-.535^{* *} \\
(.260)\end{array}$ & $\begin{array}{c}-.680 * * * \\
(.261)\end{array}$ \\
\hline $\begin{array}{l}\text { Observations } \\
\text { Pseudo } \mathrm{R}^{2}\end{array}$ & $\begin{array}{c}10,902 \\
.089\end{array}$ & & & $\begin{array}{l}5,767 \\
.109\end{array}$ \\
\hline
\end{tabular}

Note. Standard errors are in parentheses. ${ }^{* * *} p<.01,{ }^{* *} p<.05,{ }^{*} p<.10$. 
In the analysis with the restricted sample of teleworkers only, we included the independent variable, "perceived productivity gains from telework." The results are similar to the pattern reported in the full sample. In comparison to those who were teleworking before COVID-19, those who started because of COVID-19 were more likely to report that they want to telework only as an emergency measure. In contrast, they were significantly less likely to report that they want to telework on an everyday basis. Results also show that those who reported greater productivity gains from telework were more supportive of using telework on an everyday basis after COVID-19.

\section{Summary and Conclusions}

In this paper, we examined patterns of teleworking before and after the COVID-19 pandemic, in eight countries: U.S., U.K., Germany, Italy, Sweden, China, South Korea and Japan. Access to telework is important especially during a crisis such as COVID-19, because it allows people to continue working to sustain their economic wellbeing, and to avoid the risk of further infections. Monitoring access and usage of telework is thus a critical issue in both public policy and public health.

In most countries, teleworking is more commonly available in large firms, and less commonly used among small- and medium-sized enterprises (SMEs). For policy, such gaps in access may require government response, to equalize telework access across employers. For example, in April 2020, the Japanese government announced measures to promote telework among SMEs through subsidies.9

Distinguishing the timing of telework adoption before and after COVID-19 is substantively important: Those who teleworked before the pandemic did so by choice, while those who teleworked only during and after the pandemic may have been forced or

\footnotetext{
${ }^{9}$ See April 13, 2020 press release by Ministry of Economy, Trade and Industry (METI). "METI Requested Related Associations to Promote Teleworking of Workers and Other Actions as Responses to Government's Declaration of State of Emergency Involving Novel Coronavirus Disease." Available at: https://www.meti.go.jp/english/press/2020/0413_002.html
} 
pressured to. Distinguishing the voluntary versus non-voluntary nature of teleworking associates with subjective wellbeing and other qualitative measures. Our analysis shows that overall satisfaction and perceived productivity gains were significantly higher among those who were already using telework before COVID-19 than those who started after the outbreak of COVID-19.

Our findings suggest that telework can be associated with higher satisfaction and higher productivity, but only if it is done so by choice. COVID-19 was an unusual circumstance because in most advanced countries, telework was imposed by force through government order. Consequently, those who started teleworking because of COVID-19 were not necessarily happy with the circumstance, and did not realize the productivity gains that it has to offer.

Our analyses and findings here are descriptive. But we believe we have provided ample evidence to invite further investigation regarding quantitative and qualitative differences in telework adoption across countries. Future research can go deeper into contextual factors, exploring why we observe differences in teleworking across countries, and across demographic groups. 10 The sources of inequality can be multifaceted, and may be rooted in policy, technological infrastructure, work norms, social institutions, among other possibilities.

\section{Acknowledgements}

We are grateful for constructive feedback and comments from participants at the Vienna Institute of Demography Conference at the Austrian Academy of Sciences (online), Research Positioning Workshop at Hitotsubashi University Business School, Japan Politics

\footnotetext{
${ }^{10}$ For example, Lim and Tan (2020) take on a more nuanced approach to the study of qualitative and subjective outcomes from COVID-19 and working from home, by exploring the intersection of gender and marital status, and identifying areas of asymmetry. For example, they find that married women were more likely to report worsened spousal relationships, if they were working from home during COVID-19, presumably because women face higher housework expectations than do men.
} 
\& Society Webinar at Indiana University, and Inequality, Labor, and Migration Virtual Workshop at Cornell University.

\section{References}

Adams-Prassl, A., T. Boneva, M. Golin and C. Rauh. (2020). "The large and unequal impact of COVID19 on workers." Published on VOX, CEPR Policy Portal. Available at: https://voxeu.org/print/65360

Bailey, D. and N. Kurland. (2002). "A review of telework research: findings, new directions, and lessons for the study of modern work." Journal of Organizational Behavior, 23, 383-400.

Bloom, N., J. Liang, J. Roberts and Z.J. Ying. (2015). "Does Working from Home Work? Evidence from a Chinese experiment." Quarterly Journal of Economics, 130, $165-218$.

Boeri, T., A. Caiumi and M. Paccagnella. (2020). "Mitigating the work-safety trade-off." Covid Economics, 2, 60-66

Bureau of Labor Statistics (BLS). (2019). National Compensation Survey. Washington, D.C.: Bureau of Labor Statistics.

DiMaggio, P. and E. Hargittai. (2001). 'From the 'Digital Divide' to 'Digital Inequality': Studying Internet Use As Penetration Increases.” Princeton University, Center for Arts and Cultural Policy Studies, Working Paper No.15.

DiMaggio, P., E. Hargittai, W.R. Neuman and J.P. Robinson. (2001). "Social Implications of the Internet." Annual Review of Sociology, 27, 307-36.

Dingel, J. and B. Neiman. (2020). "How Many Jobs Can be Done at Home?” Becker Friedman Institute. June 2020

Gajendran, R. and D. Harrison. (2007). "The Good, the Bad, and the Unknown About Telecommuting: Meta-Analysis of Psychological Mediators and Individual Consequences." Journal of Applied Psychology, 92, 1524-1541

Huws, U., N. Jagger and S. O’Regan. (1999). “Teleworking and Globalisation.” The Institute for Employment Studies, Report 358.

Kawaguchi, D. and H. Motegi. 2020. "Who Can Work from Home? The Roles of Job Tasks and HRM Practices.” CREPE Discussion Paper 82, 2020-09. 
Lim, J. and P.L. Tan. (2020). "Weathering the Storm: The Effects of Working from Home and Income Loss on Family Relationships During COVID-19." Paper presented at Demographic Aspects of the COVID-19 Pandemic and Its Consequences, Wittgenstein Centre Conference. December 2020.

Luukinen, A. (1996). "A profile of Finnish telework: Survey results concerning the nature, extent, and potential of telework in Finland" Directions of Telework in Finland: Report by the Finnish Experience with Telework Project, 1-49

Mokhtarian, P. and I. Salomon. (1996). "Modeling the Desire to Telecommute: The Importance of Attitudinal Factors in Behavioral Models.” Transportation Research Part A: Policy and Practice, 31, 35-50

Morikawa, M. (2020). "Productivity of working from home during the COVID-19 pandemic: Evidence from an employee survey." Covid Economics, 49, 123-139

Nilles, J. (1975). "Telecommunications and organizational decentralization.” IEEE Transactions on Communications, 23, 1142-1147

OECD. (2020). "Productivity gains from teleworking in the post COVID-19 era: How can public policies make it happen?" OECD Report.

Ono, H. (2019). "Hataraku shitu wo takameru tame no kiso joken." (Conditions for improving the quality of work." Japanese Journal of Labor Studies, No. 706, 28 41.

Ono, H. and M. Zavodny. (2007). "Digital Inequality: A Five Country Comparison Using Microdata." Social Science Research, 36(3), 1135-55.

Oswald, A.J., E. Proto and D. Sgroi. (2015). "Happiness and Productivity." Journal of Labor Economics, 33, 789-822.

Raišiene, A., V. Rapuano, K. Varkulevi ciut"e and K. Stachová. (2020). "Working from Home-Who Is Happy? A Survey of Lithuania's Employees during the COVID19 Quarantine Period." Sustainability, 12, 5332.

Roscigno, V., C. Sauer and P. Valet. (2018). "Rules, Relations, and Work." American Journal of Sociology, 123, 1784-1825.

Robinson, L., S.R. Cotten, H. Ono, A. Quan-Haase, G. Mesch, W. Chen, J. Schulz, T.M. Hale and M.J. Stern. (2015). "Digital inequalities and why they matter." Information, Communication \& Society, 18, 569-582.

Robinson, L., J. Schulz, A. Khilnani, H. Ono, S.R. Cotten, N. McClain, L. Levine, W. 
Chen, G. Huang, A.A. Casilli, P. Tubaro, M. Dodel, A. Quan-Haase, M.L. Ruju, M. Ragnedda, D. Aikat and N. Tolentino. (2020). "Digital Inequalities in Time of Pandemic: COVID-19 Exposure Risk Profiles and New Forms of Vulnerability." First Monday, 25(7).

Sostero, M., S. Milasi, J. Hurley, E. Fernandez-Macias and M. Bisello. (2020).

"Teleworkability and the COVID-19 crisis: a new digital divide?" JRC Working Papers Series on Labour, Education and Technology. May 2020. 
Appendix Table 1: Descriptive Statistics.

\begin{tabular}{|c|c|c|c|c|c|c|c|c|}
\hline & $\begin{array}{c}\text { (1) } \\
\text { China }\end{array}$ & $\begin{array}{l}(2) \\
\text { U.S. }\end{array}$ & $\begin{array}{c}\text { (3) } \\
\text { Italy }\end{array}$ & $\begin{array}{c}(4) \\
\text { U.K. }\end{array}$ & $\begin{array}{c}(5) \\
\text { Sweden }\end{array}$ & $\begin{array}{c}(6) \\
\text { Germany }\end{array}$ & $\begin{array}{c}(7) \\
\text { S. Korea }\end{array}$ & $\begin{array}{c}(8) \\
\text { Japan }\end{array}$ \\
\hline$N$ & 1,673 & 1,056 & 1,320 & 1,417 & 1,349 & 1,338 & 1,385 & 1,364 \\
\hline \multicolumn{9}{|l|}{ [Demographics] } \\
\hline Age & $\begin{array}{r}41.062 \\
(11.736)\end{array}$ & $\begin{array}{r}40.813 \\
(12.877)\end{array}$ & $\begin{array}{r}44.269 \\
(11.861)\end{array}$ & $\begin{array}{r}42.675 \\
(13.014)\end{array}$ & $\begin{array}{r}42.970 \\
(12.825)\end{array}$ & $\begin{array}{r}44.404 \\
(12.778)\end{array}$ & $\begin{array}{r}44.789 \\
(11.873)\end{array}$ & $\begin{array}{r}44.809 \\
(12.664)\end{array}$ \\
\hline Female & $\begin{array}{r}0.482 \\
(0.500)\end{array}$ & $\begin{array}{r}0.421 \\
(0.494)\end{array}$ & $\begin{array}{r}0.449 \\
(0.498)\end{array}$ & $\begin{array}{r}0.480 \\
(0.500)\end{array}$ & $\begin{array}{r}0.474 \\
(0.499)\end{array}$ & $\begin{array}{r}0.472 \\
(0.499)\end{array}$ & $\begin{array}{r}0.422 \\
(0.494)\end{array}$ & $\begin{array}{r}0.402 \\
(0.490)\end{array}$ \\
\hline Married & $\begin{array}{r}0.883 \\
(0.321)\end{array}$ & $\begin{array}{r}0.549 \\
(0.498)\end{array}$ & $\begin{array}{r}0.615 \\
(0.487)\end{array}$ & $\begin{array}{r}0.514 \\
(0.500)\end{array}$ & $\begin{array}{r}0.459 \\
(0.498)\end{array}$ & $\begin{array}{r}0.466 \\
(0.499)\end{array}$ & $\begin{array}{r}0.599 \\
(0.490)\end{array}$ & $\begin{array}{r}0.563 \\
(0.496)\end{array}$ \\
\hline Family & $\begin{array}{r}0.738 \\
(0.440)\end{array}$ & $\begin{array}{r}0.510 \\
(0.500)\end{array}$ & $\begin{array}{r}0.644 \\
(0.479)\end{array}$ & $\begin{array}{r}0.538 \\
(0.499)\end{array}$ & $\begin{array}{r}0.400 \\
(0.490)\end{array}$ & $\begin{array}{r}0.360 \\
(0.480)\end{array}$ & $\begin{array}{r}0.688 \\
(0.463)\end{array}$ & $\begin{array}{r}0.540 \\
(0.499)\end{array}$ \\
\hline Urban & $\begin{array}{r}0.840 \\
(0.366)\end{array}$ & $\begin{array}{r}0.469 \\
(0.499)\end{array}$ & $\begin{array}{r}0.624 \\
(0.485)\end{array}$ & $\begin{array}{r}0.343 \\
(0.475)\end{array}$ & $\begin{array}{r}0.564 \\
(0.496)\end{array}$ & $\begin{array}{r}0.412 \\
(0.492)\end{array}$ & $\begin{array}{r}0.825 \\
(0.380)\end{array}$ & $\begin{array}{r}0.338 \\
(0.473)\end{array}$ \\
\hline $\begin{array}{l}\text { [Occupation: } \text { Omitted }= \\
\text { workers] }\end{array}$ & & & & & & & & \\
\hline Manual/ service & $\begin{array}{r}0.123 \\
(0.329)\end{array}$ & $\begin{array}{r}0.150 \\
(0.357)\end{array}$ & $\begin{array}{r}0.145 \\
(0.352)\end{array}$ & $\begin{array}{r}0.186 \\
(0.389)\end{array}$ & $\begin{array}{r}0.274 \\
(0.446)\end{array}$ & $\begin{array}{r}0.204 \\
(0.403)\end{array}$ & $\begin{array}{r}0.110 \\
(0.313)\end{array}$ & $\begin{array}{r}0.265 \\
(0.441)\end{array}$ \\
\hline Self-employed/ family & $\begin{array}{r}0.226 \\
(0.418)\end{array}$ & $\begin{array}{r}0.259 \\
(0.439)\end{array}$ & $\begin{array}{r}0.227 \\
(0.419)\end{array}$ & $\begin{array}{r}0.131 \\
(0.337)\end{array}$ & $\begin{array}{r}0.182 \\
(0.386)\end{array}$ & $\begin{array}{r}0.258 \\
(0.438)\end{array}$ & $\begin{array}{r}0.142 \\
(0.349)\end{array}$ & $\begin{array}{r}0.089 \\
(0.285)\end{array}$ \\
\hline Managers/ directors & $\begin{array}{r}0.241 \\
(0.428)\end{array}$ & $\begin{array}{r}0.188 \\
(0.391)\end{array}$ & $\begin{array}{r}0.089 \\
(0.284)\end{array}$ & $\begin{array}{r}0.193 \\
(0.395)\end{array}$ & $\begin{array}{r}0.076 \\
(0.264)\end{array}$ & $\begin{array}{r}0.111 \\
(0.314)\end{array}$ & $\begin{array}{r}0.091 \\
(0.288)\end{array}$ & $\begin{array}{r}0.095 \\
(0.293)\end{array}$ \\
\hline Part-timers & $\begin{array}{r}0.033 \\
(0.178)\end{array}$ & $\begin{array}{r}0.137 \\
(0.344)\end{array}$ & $\begin{array}{r}0.088 \\
(0.283)\end{array}$ & $\begin{array}{r}0.125 \\
(0.331)\end{array}$ & $\begin{array}{r}0.093 \\
(0.290)\end{array}$ & $\begin{array}{r}0.061 \\
(0.240)\end{array}$ & $\begin{array}{r}0.059 \\
(0.236)\end{array}$ & $\begin{array}{r}0.201 \\
(0.401)\end{array}$ \\
\hline
\end{tabular}

Note. Shown are means and standard deviations (in parentheses). 
Appendix Table 1: Descriptive Statistics (continued).

\begin{tabular}{|c|c|c|c|c|c|c|c|c|}
\hline & $\begin{array}{c}\text { (1) } \\
\text { China }\end{array}$ & $\begin{array}{l}(2) \\
\text { U.S. }\end{array}$ & $\begin{array}{l}(3) \\
\text { Italy }\end{array}$ & $\begin{array}{l}(4) \\
\text { U.K. }\end{array}$ & $\begin{array}{c}(5) \\
\text { Sweden }\end{array}$ & $\begin{array}{c}(6) \\
\text { Germany } \\
\end{array}$ & $\begin{array}{c}(7) \\
\text { S. Korea } \\
\end{array}$ & $\begin{array}{c}(8) \\
\text { Japan }\end{array}$ \\
\hline \multicolumn{9}{|l|}{$\begin{array}{l}\text { [Income quartiles: Omitted }= \\
\text { income quartile 1] }\end{array}$} \\
\hline Income quartile 2 & $\begin{array}{r}0.227 \\
(0.419)\end{array}$ & $\begin{array}{r}0.256 \\
(0.436)\end{array}$ & $\begin{array}{r}0.374 \\
(0.484)\end{array}$ & $\begin{array}{r}0.355 \\
(0.479)\end{array}$ & $\begin{array}{r}0.374 \\
(0.484)\end{array}$ & $\begin{array}{r}0.254 \\
(0.436)\end{array}$ & $\begin{array}{r}0.293 \\
(0.455)\end{array}$ & $\begin{array}{r}0.139 \\
(0.346)\end{array}$ \\
\hline Income quartile 3 & $\begin{array}{r}0.222 \\
(0.416)\end{array}$ & $\begin{array}{r}0.309 \\
(0.462)\end{array}$ & $\begin{array}{r}0.146 \\
(0.353)\end{array}$ & $\begin{array}{r}0.162 \\
(0.369)\end{array}$ & $\begin{array}{r}0.175 \\
(0.380)\end{array}$ & $\begin{array}{r}0.357 \\
(0.479)\end{array}$ & $\begin{array}{r}0.326 \\
(0.469)\end{array}$ & $\begin{array}{r}0.258 \\
(0.438)\end{array}$ \\
\hline Income quartile 4 & $\begin{array}{r}0.235 \\
(0.424)\end{array}$ & $\begin{array}{r}0.254 \\
(0.435)\end{array}$ & $\begin{array}{r}0.205 \\
(0.404)\end{array}$ & $\begin{array}{r}0.254 \\
(0.435)\end{array}$ & $\begin{array}{r}0.217 \\
(0.412)\end{array}$ & $\begin{array}{r}0.173 \\
(0.378)\end{array}$ & $\begin{array}{r}0.172 \\
(0.377)\end{array}$ & $\begin{array}{r}0.249 \\
(0.433)\end{array}$ \\
\hline Income missing & $\begin{array}{r}0.002 \\
(0.049)\end{array}$ & $\begin{array}{r}0.023 \\
(0.149)\end{array}$ & $\begin{array}{r}0.067 \\
(0.251)\end{array}$ & $\begin{array}{r}0.037 \\
(0.188)\end{array}$ & $\begin{array}{r}0.076 \\
(0.266)\end{array}$ & $\begin{array}{r}0.067 \\
(0.251)\end{array}$ & $\begin{array}{r}0.007 \\
(0.085)\end{array}$ & $\begin{array}{r}0.116 \\
(0.320)\end{array}$ \\
\hline \multicolumn{9}{|c|}{$\begin{array}{l}\text { [Firm size categories: Omitted }=\text { Less than } 5 \\
\text { employees }]\end{array}$} \\
\hline 5 to 99 & $\begin{array}{r}0.386 \\
(0.487)\end{array}$ & $\begin{array}{r}0.294 \\
(0.456)\end{array}$ & $\begin{array}{r}0.381 \\
(0.486)\end{array}$ & $\begin{array}{r}0.289 \\
(0.454)\end{array}$ & $\begin{array}{r}0.324 \\
(0.468)\end{array}$ & $\begin{array}{r}0.340 \\
(0.474)\end{array}$ & $\begin{array}{r}0.453 \\
(0.498)\end{array}$ & $\begin{array}{r}0.322 \\
(0.467)\end{array}$ \\
\hline 100 to 299 & $\begin{array}{r}0.248 \\
(0.432)\end{array}$ & $\begin{array}{r}0.148 \\
(0.355)\end{array}$ & $\begin{array}{r}0.100 \\
(0.300)\end{array}$ & $\begin{array}{r}0.148 \\
(0.355)\end{array}$ & $\begin{array}{r}0.118 \\
(0.323)\end{array}$ & $\begin{array}{r}0.151 \\
(0.358)\end{array}$ & $\begin{array}{r}0.129 \\
(0.336)\end{array}$ & $\begin{array}{r}0.136 \\
(0.343)\end{array}$ \\
\hline 300 to 999 & $\begin{array}{r}0.250 \\
(0.433)\end{array}$ & $\begin{array}{r}0.214 \\
(0.410)\end{array}$ & $\begin{array}{r}0.115 \\
(0.319)\end{array}$ & $\begin{array}{r}0.145 \\
(0.352)\end{array}$ & $\begin{array}{r}0.153 \\
(0.360)\end{array}$ & $\begin{array}{r}0.168 \\
(0.374)\end{array}$ & $\begin{array}{r}0.080 \\
(0.272)\end{array}$ & $\begin{array}{r}0.127 \\
(0.333)\end{array}$ \\
\hline 1000 or more & $\begin{array}{r}0.069 \\
(0.254)\end{array}$ & $\begin{array}{r}0.213 \\
(0.410)\end{array}$ & $\begin{array}{r}0.102 \\
(0.303)\end{array}$ & $\begin{array}{r}0.224 \\
(0.417)\end{array}$ & $\begin{array}{r}0.188 \\
(0.390)\end{array}$ & $\begin{array}{r}0.164 \\
(0.371)\end{array}$ & $\begin{array}{r}0.090 \\
(0.287)\end{array}$ & $\begin{array}{r}0.229 \\
(0.421)\end{array}$ \\
\hline Government/ public sector & $\begin{array}{r}0.008 \\
(0.088)\end{array}$ & $\begin{array}{r}0.021 \\
(0.143)\end{array}$ & $\begin{array}{r}0.041 \\
(0.198)\end{array}$ & $\begin{array}{r}0.064 \\
(0.244)\end{array}$ & $\begin{array}{r}0.090 \\
(0.286)\end{array}$ & $\begin{array}{r}0.024 \\
(0.153)\end{array}$ & $\begin{array}{r}0.018 \\
(0.133)\end{array}$ & $\begin{array}{r}0.037 \\
(0.421)\end{array}$ \\
\hline
\end{tabular}

Note. Shown are means and standard deviations (in parentheses). 


\section{Appendix Table 2: Occupational Categories.}

Q: What is your occupation?

Select the appropriate answer from those below.

* If you have more than one occupation, please select your

primary one.

Office work (general office worker, etc.)

Specialist/teacher (researcher, engineer, judge, teacher at elementary/junior high/high school, etc.)

Office workers

Field sales/service work (sales staff, etc.)

Desk sales/service work (sales assistant, staff at restaurant, receptionist, etc.)

Labor work (production line worker at a plant, construction worker, driver, tradesman, etc.)

Self-employed in farming, forestry or fisheries work Family business in farming, forestry or fisheries work Self-employed in commerce/services industry Family business in commerce/services industry Self-employed/ family

Freelance (doctor with private practice, lawyer, writer, person of religion, artist, etc.)

Administrative work (section chief or higher in a public office, private corporation, or other organization)

Officer of a company or other organization

Part-time worker (long-term part-time worker) Homemaker with a part-time job 